\title{
EDITORIAL
}

\section{Translational research in respiratory medicine}

\author{
R. Farré* and A.T. Dinh-Xuan\#
}

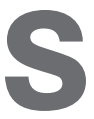
cientific research and the development of modern powerful techniques [1] are crucial for improving patient care in a society that is increasingly demanding the highest quality health services. Indeed, effective patient care requires the continuous improvement of knowledge on the pathophysiology of the diseases, diagnostic procedures and therapeutic tools available. To this end, development of both clinical and basic research in health sciences is required. However, what is most effective in improving medical knowledge, and hence patient care, is the cross-fertilisation between basic and clinical science. This has been specifically highlighted in recent years with the coining of the term "translational research" [2]. Translational research is of great importance in all medical specialties, including respiratory medicine.

To review the contribution of translational research in the current understanding of respiratory disorders, a new series entitled "Cell and animal studies in respiratory medicine" is launched in this issue of the European Respiratory Journal (ERJ). This series is not conceived as a conventional state-of-the-art analysis. Instead, its aim is to provide basic science and clinically oriented researchers with a perspective of past, current and expected contributions of cell and animal studies to respiratory disorders in the context of translational research. The series will initially address six relevant subjects covering a wide spectrum of respiratory diseases: acute lung injury [3]; asthma; chronic obstructive pulmonary disease (COPD); pulmonary hypertension; respiratory infections; and sleep apnoea.

As will be clearly shown by the reviews in this series, the relative importance of cell and animal studies in the literature of different respiratory disorders differs among subjects. To illustrate this point, figure 1 shows the ratio between the number of studies classified as "animal" and "human" in a PubMed search using the terms "acute lung injury", "asthma", "COPD", "pulmonary hypertension", "respiratory infections" and "sleep apnoea" for two periods: from January 1, 1998 to December 31, 2002; and from January 1, 2003 to July 23, 2007. While, in some subjects, the contribution of animal studies to the literature was remarkable, in others it was scarce. These

*Biophysics and Bioengineering Unit, Faculty of Medicine, Barcelona University-IDIBAPS and CIBER Enfermedades Respiratorias, Barcelona, Spain. "Dept of Respiratory Physiology, Faculty of Medicine, EA 2511, Paris Descartes University, Hôpital Cochin, Paris, France.

STATEMENT OF INTEREST: None declared.

CORRESPONDENCE: R. Farré, Facultat de Medicina, Unitat de Biofísica i Bioenginyería, Casanova 143, Barcelona, 08036 Spain. Fax: 34 934024515. E-mail: rfarre@ub.edu

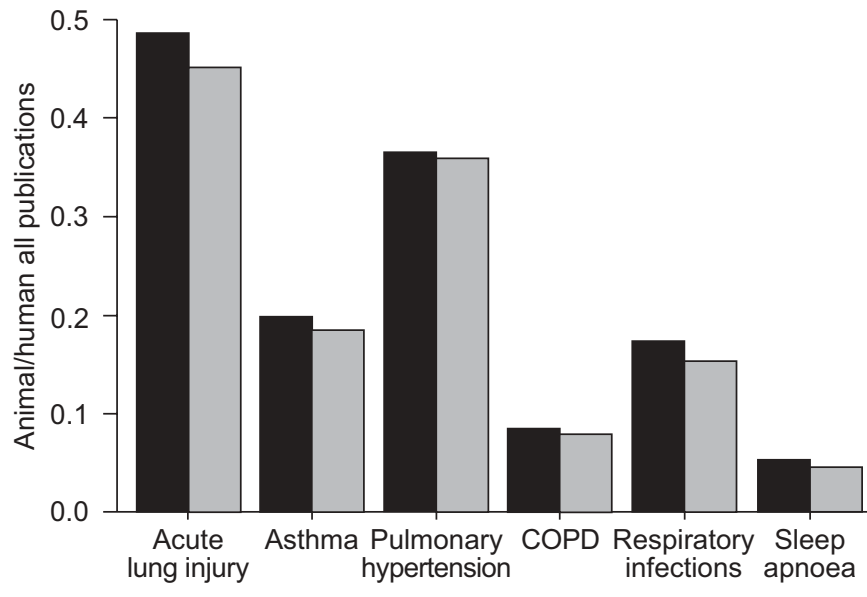

FIGURE 1. Ratio of published papers classified as "animal" and "human" according to a PubMed search for different areas of respiratory medicine between 1998-2002 (匹) and 2003-2007 (ロ). COPD: chronic obstructive pulmonary disease.

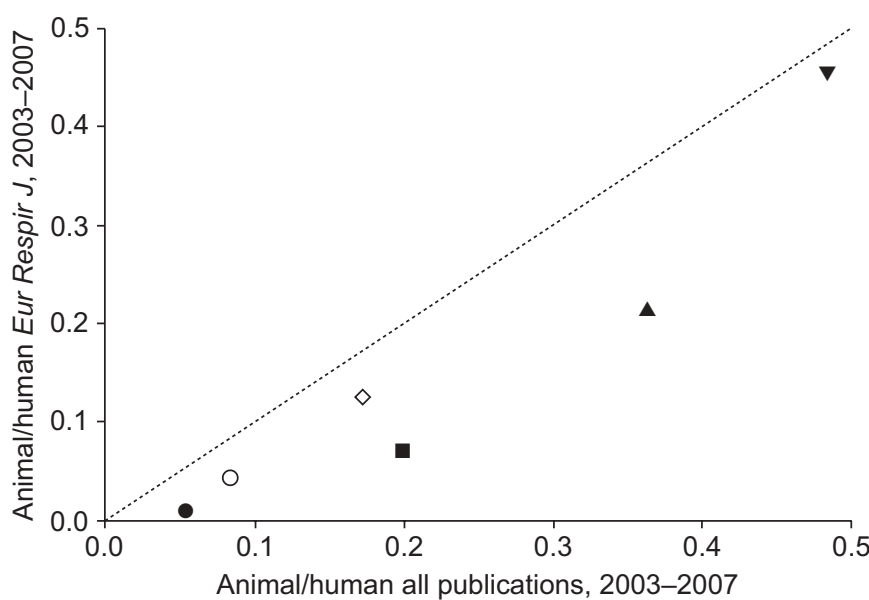

FIGURE 2. Ratio of papers classified as "animal"/ "human" published by the European Respiratory Journa/ with respect to animal/human papers published by all journals included in a PubMed search for different areas of respiratory medicine in the time-period 2003-2007. • : sleep apnoea; O: chronic obstructive pulmonary disease; $\mathbf{\square}$ : asthma; $\diamond$ : respiratory infections; $\mathbf{\Delta}$ : pulmonary hypertension; acute lung injury; $\cdots \cdots . .$. : identity line.

differences could be explained by the difficulty in designing adequate animal models for each disease [4] and by the different prevalence of each pathology [5]. Interestingly, the relative contribution of animal studies was virtually the same 
in the two periods, with a very slight and systematic increase in the last period, which suggests that the effort devoted to basic science and the results obtained have been maintained during this $10-y r$ period. Figure 2 shows the search results obtained when comparing the references published by the ERJ and by all journals included in PubMed for the last period. The fact that, in general, ERJ data are below the identity line probably reflects that, contrary to journals mainly focused on biomedical basic science, the ERJ publishes both basic and clinical studies. The correlation observed in the figure suggests that the ERJ has published a reasonable proportion of basic and clinical science articles in each subject [6].

To pursue the promotion of translational research, the Editorial Board launches this series with the hope of bringing the European Respiratory Journal readership up to date on the role played by basic science in the understanding of respiratory medicine.

\section{REFERENCES}

1 Bowler RP, Ellison MC, Reisdorph N. Proteomics in pulmonary medicine. Chest 2006; 130: 567-574.

2 Hörig H, Marincola E, Marincola FM. Obstacles and opportunities in translational research. Nat Med 2005; 11: 705-708.

3 Oeckler RA, Hubmayr RD. Ventilator-associated lung injury: a search for better therapeutic targets. Eur Respir J 2007; 30: 1216-1226.

4 Shaffer TH, Wolfson MR, Shaffer TH. If art imitates life, can laboratory models imitate clinical disease processes? Crit Care Med 2002; 30: 2399-2400.

5 European Respiratory Society/European Lung Foundation. European Lung White Book. The First Comprehensive Survey on Respiratory Health in Europe. Loddenkemper R, Gibson GJ, Sibille Y, eds. Sheffield, UK, ERSJ, 2003.

6 Sterk PJ, Rabe KF. What else can you expect at www.erj. ersjournals.com? Eur Respir J 2007; 29: 1-3. 